\title{
Combined Homeopathy and Allopathy Treatment for COVID-19: A Review
}

\author{
Md. Irfanul Haque ${ }^{1}$, Aqib Adnan Shafin², Md. Mahmud ${ }^{3}$
}

${ }^{1}$ Post Graduate Student [M.Sc], Department of Applied Chemistry and Chemical Engineering, Bangabandhu Sheikh Mujibur Rahman Science and Technology University, Gopalganj, Bangladesh; ${ }^{2}$ Graduate Student [B.Sc], Department of Applied Chemistry and Chemical Engineering, Bangabandhu Sheikh Mujibur Rahman Science and Technology University, Gopalganj, Bangladesh; ${ }^{3}$ Post Graduate Student [M.Sc], Department of Applied Chemistry and Chemical Engineering, Bangabandhu Sheikh Mujibur Rahman Science and Technology University, Gopalganj, Bangladesh

[Received: 17 August 2020; Accepted: 28 September 2020]

\begin{abstract}
At the end of 2019, an outburst of a novel virus called severe acute respiratory syndrome coronavirus 2 (SARS-CoV-2) was observed in Wuhan, China. World Health Organization proclaimed this upsurge as a Public Health Emergency of International Concern on 30th January 2020. In this article, epidemiology, the causative agent, pathogenesis of SARS-CoV-2 and its treatment approaches like homeopathy and allopathy are reviewed. However, our main focus was to collect and visualize some data which bring evidence that combined homeopathy and allopathy treatment can help to cure COVID-19. [Bangladesh Journal of Infectious Diseases, October 2020;7(suppl_2):S38-S45]

Keywords: COVID-19; comparative mortality rate; homeopathy; allopathy; clinical trials

Correspondence: Md. Mahmud, Post Graduate Student [M.Sc], Department of Applied Chemistry and Chemical Engineering, Bangabandhu Sheikh Mujibur Rahman Science and Technology University, Gopalganj-8100, Bangladesh; Email: hasan.mahmud.edu@ gmail.com; Cell no.: +8801773436385; ORCID: https://orcid.org/0000-0002-1487-2876

Conflict of interest: The authors declare that there are no conflicts of interest.

Funding agency: The study was not funded by any authority.

Contribution to authors: Md. Irfanul Haque, Aqib Adnan Shafin involved in data collection and literature search up to manuscript writing. Md. Mahmud involved in revision of this manuscript.

How to cite this article: Haque MI, Shafin AA, Mahmud. Combined Homeopathy and Allopathy Treatment for COVID-19: A Review. Bangladesh J Infect Dis 2020;7(suppl_2):S38-S45

Copyright: (2020. Haque et al. Published by Bangladesh Journal of Infectious Diseases. This article is published under the Creative Commons CC BY-NC License (https://creativecommons.org/licenses/by-nc/4.0/). This license permits use, distribution and reproduction in any medium, provided the original work is properly cited, and is not used for commercial purposes.
\end{abstract}

\section{Introduction}

COVID-19, an infectious lethal virus is being fought by the whole world ${ }^{1}$. China alerted WHO on several cases of pneumonia in Wuhan city on December 31, 2019. A novel coronavirus shortly named as 2019-nCoV by WHO was recognized from the throat swab sample of a patient on January 7, 2020. This virus was later renamed as severe acute respiratory syndrome coronavirus 2 (SARS-
CoV-2) \& the disease was named as COVID-19 by WHO. On January 7,2020, WHO declared the SARS-CoV-2 outbreak as a Public Health Emergency of International Concern (PHEIC) ${ }^{2}$.

It is found through studies that the virus can infect people from a distance of about $6 \mathrm{ft}(1.8 \mathrm{~m})$. It can survive for 2 hours to a few days in the cough \& sneezing droplets that fall on the surface or ground. An infection may be caused by touching an object 
or surface which has already a virus but it is not the major course of the infection ${ }^{3}$. The most common symptoms of COVID-19 are fever, dry cough, dyspnoea, chest pain, fatigue \& myalgia. Less common symptoms include headache, dizziness, abdominal pain, diarrhea, nausea, and vomiting ${ }^{2}$.

Coronaviruses are enveloped viruses with nonsegmented, single-stranded and positive-sense RNA genomes that can infect a variety of vertebrates (such as pigs \& chickens). Six coronaviruses have been found to infect and cause respiratory diseases in human hosts. Among these viruses, severe acute respiratory syndrome coronavirus (SARS-CoV) \& Middle East respiratory syndrome coronavirus (MARS-CoV) are highly pathogenic coronaviruses that have resulted in regional and global outbreaks. The RNA genome of these viruses is the longest among RNA viruses, which ranges from 26,000 to 32,000 bases. CoVs mainly cause respiratory and intestinal infections with an array of clinical manifestations ${ }^{1}$. The world has developed more than 150 coronavirus vaccines. Vaccines go through three clinical trial phases before going to regulatory agencies for approval. So it can typically take 10 to 15 years to bring a vaccine to market ${ }^{4}$.

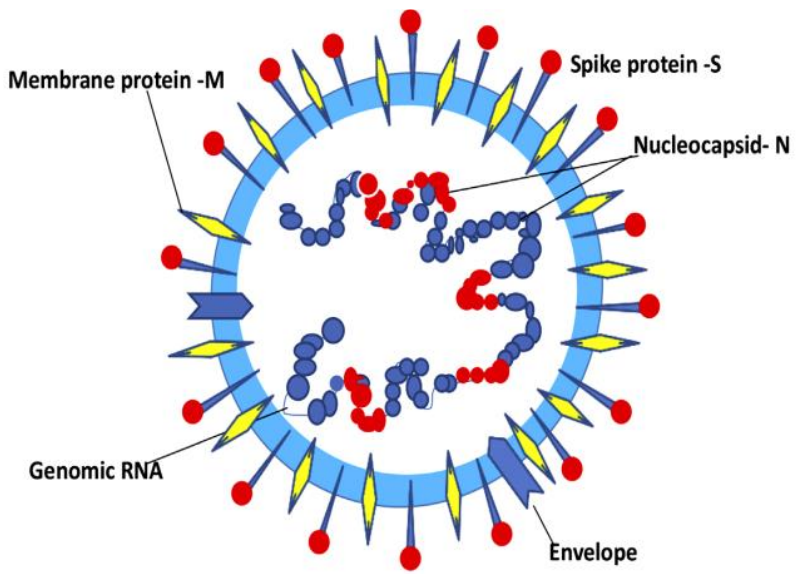

Figure I: Diagrammatic expression of a coronavirus virion: Various structural proteins which form the coronavirus particle and the genome, single-stranded RNA are shown ${ }^{5}$.

SARS-CoV-2 is a member of the Coronaviridae family and Nidovirales order, which contains two subfamilies, Coronavirinae and Torovirinae, and members of the subfamily Coronavirinae are subdivided into four genera: (a) Alphacoronavirus which contains the human coronavirus ( $\mathrm{HCoV})$ 229E and HCoV-NL63; (b) Betacoronavirus includes HCoV-OC43, Severe Acute Respiratory Syndrome human coronavirus (SARS-HCoV), HCoV-HKU1, and Middle Eastern respiratory syndrome coronavirus (MERS-CoV); (c) Gammacoronavirus includes viruses of birds and whales and; (d) Deltacoronavirus includes viruses of birds and pigs ${ }^{2}$. A Further study found that the virus is more related to BatCoV RaTG13, a bat coronavirus that was previously detected in Rhinolophus Affinis from Yunnan Province, with $96.2 \%$ overall genome sequence identity. Altogether, these findings suggest that bats might be the original host of this virus ${ }^{2}$.

\section{Mechanism of action to attacking the host cell}

The infected individuals primarily spread the virus from his respiratory droplets in closed spaces and to a much lesser extent by fomites, to mucosal epithelial cells in the upper airway and oral cavity. Here, the virus latches onto host cell ACE2 (angiotensin-converting enzyme-2) receptor binding sites by using its trimeric Spike protein, via the receptor-binding domain (RBD) of this glycoprotein in the "prefusion" state. Proteases such as TMPRSS-2/furin cleave viral Spike to enable membranes of the virus and host cell to fuse. The virus enters cells by endocytosis. To translate the viral replication-transcription complex (RTC) in a double membrane vesicle the $30 \mathrm{~kb}$ single-stranded plus-strand RNA is released directly into the cytoplasm and hijacks the cell. The RTC then produces RNAs that translate into protein, the ORFs coding for four main structural proteins, sixteen nonstructural proteins, and some special proteins. Virions are assembled with RNA caused by a nucleocapsid $(\mathrm{N})$ and a "coat" made up of spike (S) proteins, membrane $(\mathrm{M})$, and envelope $(\mathrm{E})$. When the virus is released, it can infect cells in the lower airways (Type II pneumocytes) and enterocytes in the gastrointestinal tract ${ }^{6}$.

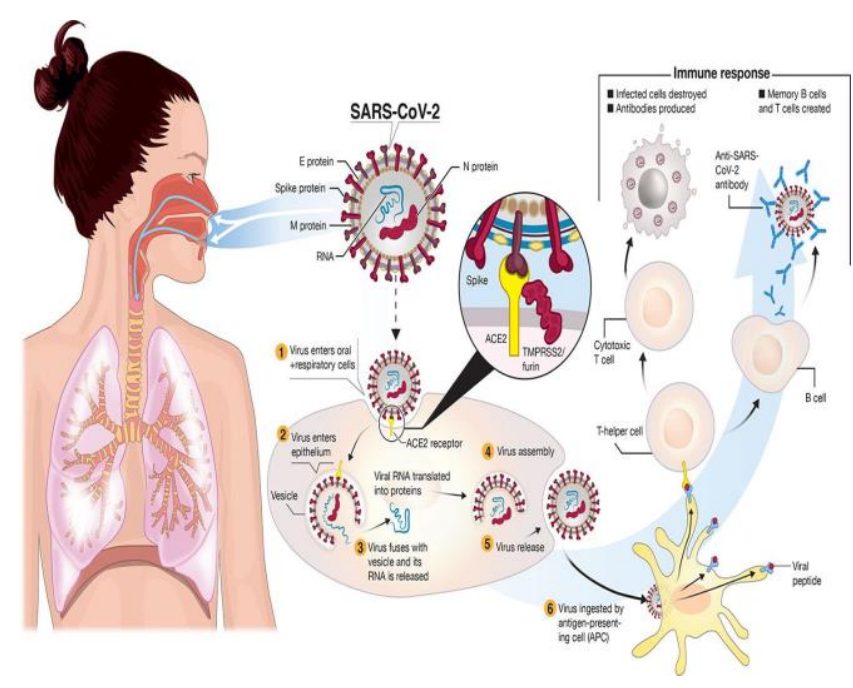

Figure II: Transmission and life-cycle of SARSCoV-2 causing COVID-196 
Comparative Mortality Rate under Homeopathy \& Allopathy in Previous Pandemics

Dr. Routh, an allopathic physician from Britain, was an allotted authority by the medical appointee of London to list a mortality-statistics for all diseases. After studying of total 32,655 homeopathic cases, and 119,630 allopathic cases from several hospitals of England, Austria, and Germany, in 1852 he was strained to give evidence against Allopathy. The recorded mortality rate under homeopathic treatment was $4.4 \%$, and the under allopathic treatment mortality rate was $10.5 \%$. Available data is visualized in a figure III.

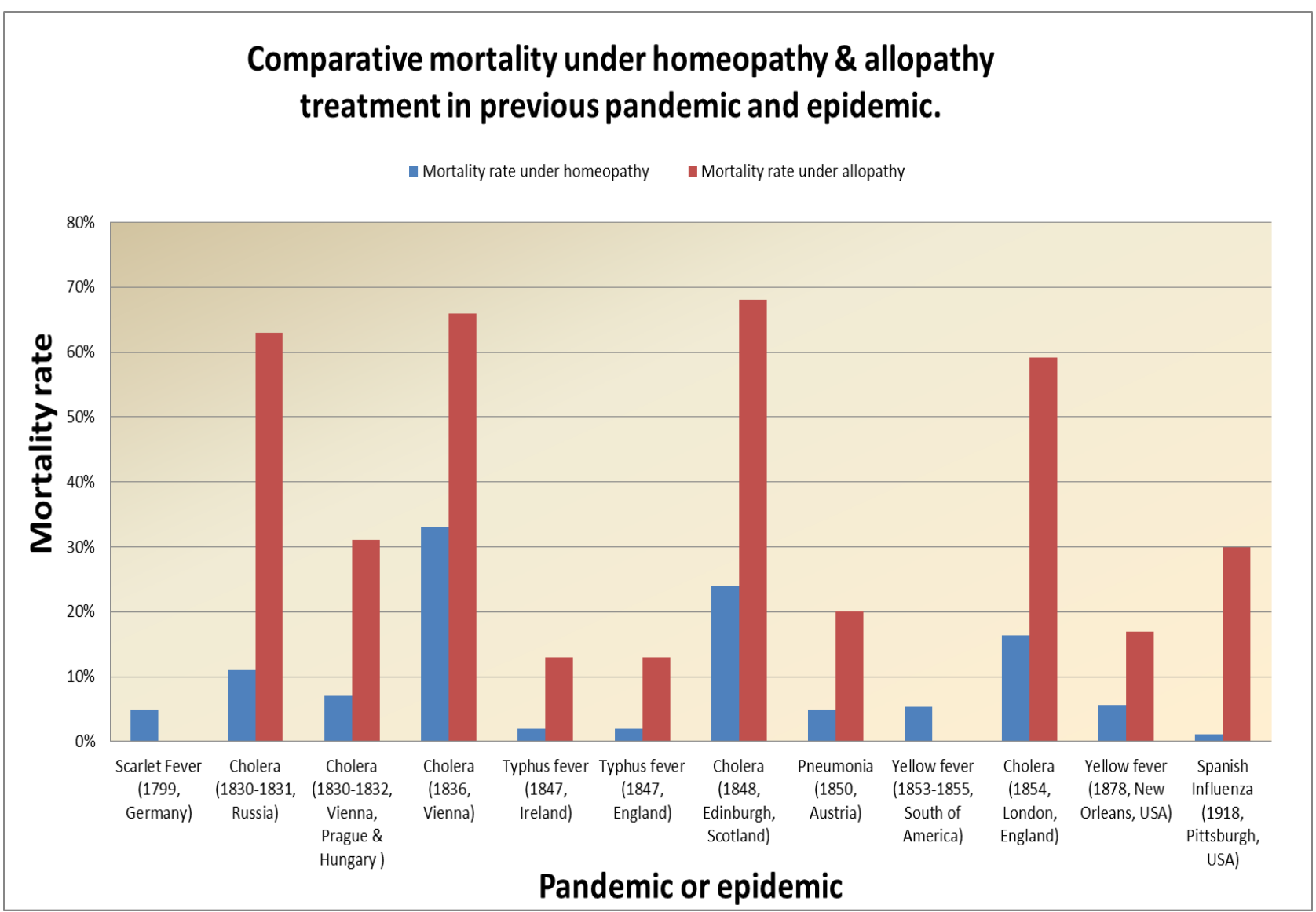

Figure III: Column chart of comparative mortality rate under homeopathy and allopathy treatment in previews epidemic and pandemic ${ }^{7}$

\section{Homeopathic Approach}

Homeopathic treatment is reliable with the historical use of homeopathic mediations during pandemics. Currently, there is no available vaccine and certain therapies for COVID-19 but several studies are advancing to put the name of a safe and effective traditional drug.

Except some certain conventional medicines available, homeopathy provides an alternative treatment for those COVID-19 patients with mild to moderate symptoms who are recovering at home, probably saving them from hospitalization ${ }^{8}$.

\section{Some clinical trial of homeopathy}

There are several clinical trial data available from different parts of the world conveying the proof of the effectiveness of the homeopathic drug to prevent and cure COVID-19. The following are some data on recent clinical trials.

\section{Hong Kong trial}

A homeopathic clinical trial data was available from Homeopathy Research Institute, Hong Kong. The trial was conducted on 18 people of 6 different clusters. All of them were treated successfully with homeopathic medication. 
Table 1: Recorded data from Hong Kong trial

\begin{tabular}{|c|c|c|c|c|c|}
\hline Cluster no & Case no & Age & Gender & Infection confirming test & Treated with \\
\hline Custer 1 & Case 1 & 62 & Female & $\begin{array}{l}\text { Close contacts with RT-PCR } \\
\text { positive case }\end{array}$ & Bryonia alb 30C \\
\hline Cluster 2 & Case 1 & 21 & Male & RT-PCR & Bryonia alb 30C \\
\hline \multirow[b]{5}{*}{ Cluster 3} & Case 1 & 18 & Female & Serology & Bryoniaalb 30C \\
\hline & Case 2 & 21 & Female & Serology & Gelsemium 30C \\
\hline & Case 3 & 20 & Female & Serology & Gelsemium 30C \\
\hline & Case 4 & 19 & Female & Serology & Gelsemium 30C \\
\hline & Case 5 & 22 & Female & Serology & Gelsemium 30C \\
\hline \multirow[b]{5}{*}{ Cluster 4} & Case 1 & 24 & Male & Serology & Gelsemium 30C \\
\hline & Case 2 & 27 & Male & Serology & Gelsemium 30C \\
\hline & Case 3 & 20 & Female & Serology & Arsenicum alb30C \\
\hline & Case 4 & 33 & Male & Serology & Gelsemium 30C \\
\hline & Case 5 & 21 & Male & Serology & Gelsemium 30C \\
\hline \multirow[b]{5}{*}{ Cluster 5} & Case 1 & 23 & Male & Serology & Gelsemium 30C \\
\hline & Case 2 & 24 & Male & Serology & Gelsemium 30C \\
\hline & Case 3 & 23 & Male & Serology & Gelsemium 30C \\
\hline & Case 4 & 22 & Male & Serology & Gelsemium 30C \\
\hline & Case 5 & 33 & Male & Serology & Eupatorium perf $30 \mathrm{C}$ \\
\hline Cluster 6 & Case 1 & 49 & Female & $\begin{array}{l}\text { Close contact with RT-PCR } \\
\text { positive case }\end{array}$ & Bryonia alba $200 \mathrm{C}$ \\
\hline
\end{tabular}

Data source .

\section{New York trial}

A disorder similar to flu has appeared in New York at the starting of 2020. Later in February 2020, it was clear that the flue was due to the novel coronavirus (SARS-CoV-2). A data was recorded in New York which indicates that several patients were responding well to homeopathy. Tabulated data of 5 cases are given below.

Table 2: Recorded data from New York trial

\begin{tabular}{|l|l|l|l|l|}
\hline Case no & Age & Gender & Infection confirming test & Treated with \\
\hline Case 1 & 35 & Male & IgG antibody test & Gelsimium 30C, Senega 200C \\
\hline Case 2 & - & - & IgG antibody test & Senega \\
\hline Case 3 & - & - & IgG antibody test & Senega \\
\hline Case 4 & 2 & - & IgG antibody test & Senega 200C \\
\hline Case 5 & 77 & Female & IgG antibody test & Arsenic Alb \\
\hline
\end{tabular}

Data source $^{8}$

\section{Italian trial}

In Italy, 50 cases examined consisted of 29 females, 20 males and in one case the gender was not specified. There were 4 pediatric cases out of 50 . They were treated with homeopathy and the hospitalization rate in this group of 50 patients treated homeopathically for COVID-19 was 0 though hospitalization rate was $20.4 \%$ in Italy regardless of their symptomatological status

\section{Keynote prescription of Homeopathy}

Several notable features or distinct amalgamation of symptoms that lead the concentration to a specific medicine. Homeopathic drugs were confirmed by Homeopathic MateriaMedica which was written by Boericke and Allen. Single medicine was prescribed as per the Law of Similia. Medicine and the corresponding symptom have been mentioned below. 


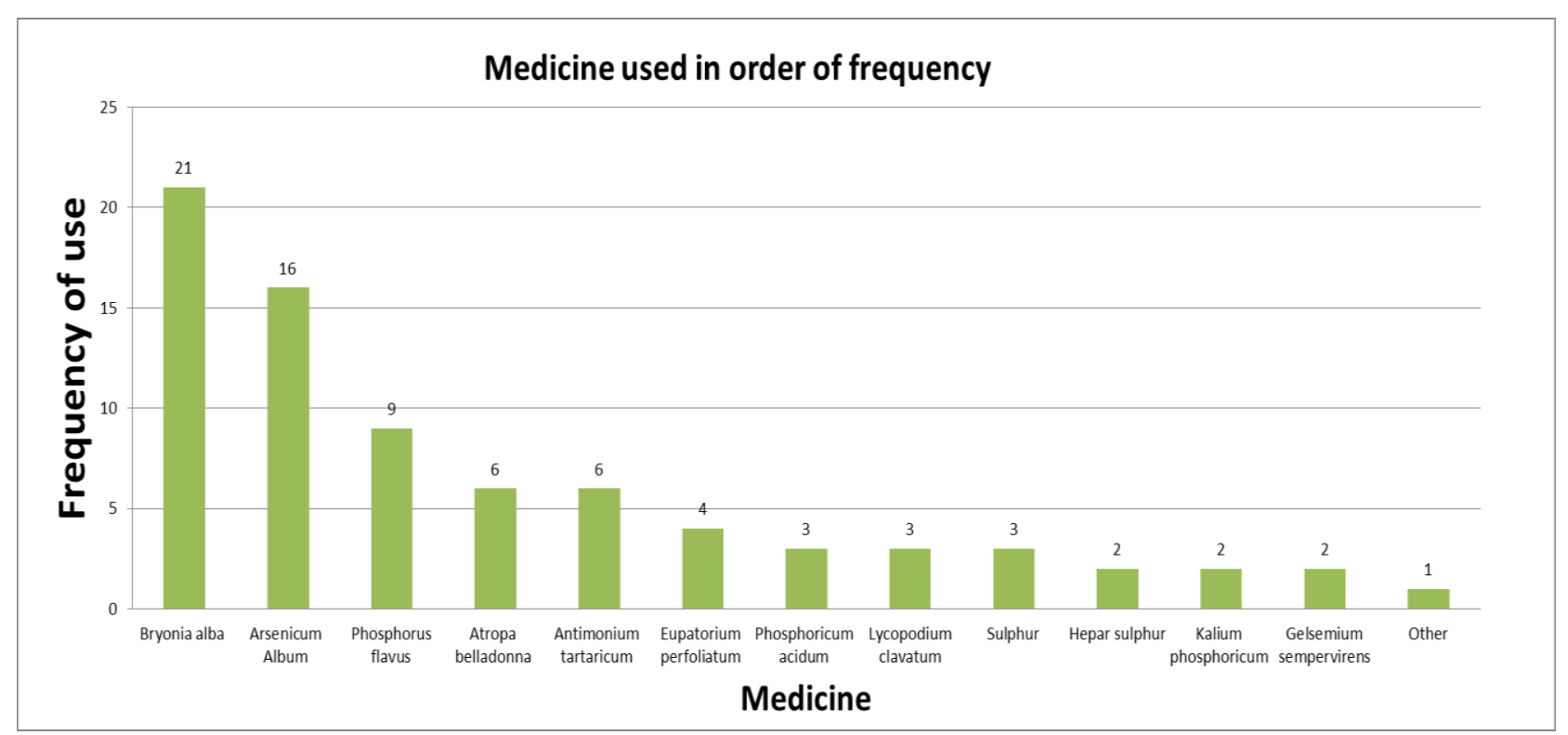

Figure IV: Column chart of medicine used in order of frequency ${ }^{10}$.

Table 3: Symptom and Corresponding Medicine That Helped In Cure

\begin{tabular}{|c|c|c|}
\hline Medicine & Symptom & Dose \\
\hline Arsenic 30C & $\begin{array}{c}\text { Panic of the } \\
\text { pandemic, fear of } \\
\text { demise. }\end{array}$ & Thrice a day \\
\hline Aconite $30 \mathrm{C}$ & $\begin{array}{c}\text { Unexpected } \\
\text { inception of any } \\
\text { symptom with fear } \\
\text { of demise. }\end{array}$ & Thrice a day \\
\hline $\begin{array}{l}\text { Belladonna } \\
\text { 30C }\end{array}$ & $\begin{array}{l}\text { Unexpected onset of } \\
\text { symptoms with } \\
\text { congestion. }\end{array}$ & Thrice a day \\
\hline Bryonia 30C & $\begin{array}{c}\text { Fever with muscle } \\
\text { pain, with or without } \\
\text { cough. }\end{array}$ & Thrice a day \\
\hline $\begin{array}{l}\text { Eupatorium } \\
30 \mathrm{C}\end{array}$ & $\begin{array}{c}\text { Intense pain, } \\
\text { pyrexia, and flu-like } \\
\text { indication. }\end{array}$ & Thrice a day \\
\hline Wyethia 30C & $\begin{array}{l}\text { Wheezing, flaring } \\
\text { throat with dryness. }\end{array}$ & Thrice a day \\
\hline $\begin{array}{l}\text { Gelsemium } \\
\text { 30C }\end{array}$ & $\begin{array}{l}\text { Utmost sickness } \\
\text { with Flu-like sign. }\end{array}$ & Thrice a day \\
\hline
\end{tabular}

Data source ${ }^{11}$.

\section{Allopathic Approach}

Some of the potential drugs are under clinical trials.

\section{Remdesivir (GS-5734)}

Remdesivir is an ebola drug developed by Gilead Sciences that was found to be ineffective is now being tested in two phases III randomized clinical trials in Asian countries. The National Institute of Allergy and Infectious Diseases released results from its study showing patients who took remdesivir usually recovered faster than those who didn't take the $\operatorname{drug}^{12,13}$.

\section{Chloroquine}

Chloroquine, has been in the pharmaceutical industry for 50 years now. Chloroquine has a very low cost \& is available in most countries of the world. But the usage of Chloroquine requires frequent monitoring because of its adverse side effects ${ }^{1}$.

\section{ChAdOx1 nCoV-19}

Oxford University has developed an adenovirus vaccine vector called ChAdOx1 nCoV-19. This vaccine is a genetically modified virus that causes the common cold in chimpanzees. However, the virus has been modified so that it doesn't cause infection in people and also to mimic the coronavirus which will trigger an immune response $\mathrm{e}^{12,14}$. 


\section{INO-4800}

This one is a nucleic-acid based vaccine and can be kept at room temperature for more than a year without any degradation. It does not require to be frozen, in transport, or for years of storage. Inovio made its potential vaccine by adding genetic material of the virus inside synthetic DNA, which researchers hope will cause the immune system to make antibodies against $\mathrm{it}^{15,16}$.

\section{mRNA-1273}

It is an mRNA-based vaccine that has been developed to work against the S protein of SARS$\mathrm{CoV}-2$. The $\mathrm{S}$ protein complex is necessary for membrane fusion and host cell infection and has been the target of vaccines against the coronaviruses ${ }^{17,18}$.

Table 4: Brief Summary of Some Allopathic Drugs

\begin{tabular}{|c|c|c|c|c|}
\hline Drugs & Mechanism of action & $\begin{array}{l}\text { Approved } \\
\text { dosage }\end{array}$ & $\begin{array}{c}\text { Current trial } \\
\text { phase }\end{array}$ & Company name \\
\hline Remdesivir & $\begin{array}{l}\text { It is designed to slow or stop the } \\
\text { virus from creating copies of } \\
\text { itself by blocking the viral } \\
\text { enzyme called RNA-dependent } \\
\text { RNA polymerase }(\mathrm{RdRp})^{19} \text {. }\end{array}$ & $\begin{array}{l}\text { 1st day-200mg } \\
\text { then } 100 \mathrm{mg} \text { for } \\
\text { nine day }{ }^{20}\end{array}$ & Phase $-3^{12}$. & $\begin{array}{c}\text { Gilead } \\
\text { Sciences }^{12} \text {. }\end{array}$ \\
\hline Choloroquine & $\begin{array}{l}\text { It interferes with the } \\
\text { glycosylation of cellular } \\
\text { receptor, angiotensin-converting } \\
\text { enzyme } 2 \text { (ACE-2) of SARS- } \\
\text { CoV to block viral infection }{ }^{21} \text {. }\end{array}$ & $\begin{array}{c}500 \mathrm{mg}, 2 \\
\text { times/day }{ }^{22} \text {. }\end{array}$ & $\begin{array}{l}\text { Approved for } \\
\text { emergency } \\
\text { use only }{ }^{12} \text {. }\end{array}$ & $\begin{array}{c}\text { US Food \& Drug } \\
\text { Administration } \\
(\text { FDA })^{12} .\end{array}$ \\
\hline $\begin{array}{l}\text { ChAdOx1 } \\
\text { nCoV-19 }\end{array}$ & $\begin{array}{l}\text { It has been engineered to express } \\
\text { the SARS-CoV-2 spike protein } \\
\text { that will train the human body to } \\
\text { recognize and develop an } \\
\text { immune response to the spike } \\
\text { glycoprotein, which will help } \\
\text { stop the virus from entering } \\
\text { human cells }{ }^{23} \text {. }\end{array}$ & $\begin{array}{l}\text { Three doses }-5 \\
\times 10^{9} \text { viral } \\
\text { particles, } 2 \cdot 5 \times \\
10^{10} \text { viral } \\
\text { particles, and } 5 \\
\times 10^{10} \text { viral } \\
\text { particles }^{24} \text {. }\end{array}$ & Phase $-3^{25}$. & $\begin{array}{c}\text { University of } \\
\text { Oxford }^{25}\end{array}$ \\
\hline INO-4800 & $\begin{array}{l}\text { It is a DNA vaccine that } \\
\text { generates antibodies neutralizing } \\
\text { both the earlier strain of the virus } \\
\text { as well as the mutant variant } \\
\text { (D614G) that has emerged with } \\
\text { greater infectivity }{ }^{26} \text {. }\end{array}$ & $\begin{array}{l}\text { Two doses - } 1.0 \\
\text { mg, four weeks } \\
\text { apart }^{27} .\end{array}$ & Phase $-2 / 3^{26}$ & $\begin{array}{c}\text { Inovio } \\
\text { Pharmaceuticals } \\
\text { and Beijing } \\
\text { Advaccine } \\
\text { Biotechnology }{ }^{12} \text {. }\end{array}$ \\
\hline mRNA-1273 & $\begin{array}{l}\text { It injects snippets of a virus's } \\
\text { genetic material, in this case, } \\
\text { mRNA, into human cells which } \\
\text { creates viral proteins that mimic } \\
\text { the coronavirus, training the } \\
\text { immune system to recognize its } \\
\text { presence. }\end{array}$ & $\begin{array}{l}\text { Two doses - } 25 \\
\text { microgram } \\
(\mathrm{mcg}), 100 \mathrm{mcg} \\
\text { or } 250 \mathrm{mcg} \text { dose, } \\
28 \text { days apart }{ }^{18} \text {. }\end{array}$ & Phase $-3^{4}$. & $\begin{array}{l}\text { Moderna and the } \\
\text { National } \\
\text { Institutes of } \\
\text { Health }^{12} \text {. }\end{array}$ \\
\hline
\end{tabular}


Table 5: Recorded data from Bhopal trial ${ }^{11}$

\begin{tabular}{|c|c|c|c|c|c|c|}
\hline $\begin{array}{l}\text { Cluster } \\
\text { no }\end{array}$ & $\begin{array}{l}\text { Case } \\
\text { no }\end{array}$ & Age & Gender & Homeopathy & Allopathy & Test method \\
\hline \multirow{3}{*}{ Cluster 1} & \multirow{3}{*}{ Case 1} & \multirow{3}{*}{48} & \multirow{3}{*}{ Female } & Arsenic 30C & \multirow{3}{*}{$\begin{array}{l}\text { Hydroxychloroquine } \\
400 \mathrm{mg}\end{array}$} & \multirow{3}{*}{$\begin{array}{ll}\text { Confirmed } & \\
\text { (method not } \\
\text { mentioned) }\end{array}$} \\
\hline & & & & Arsenic 200C & & \\
\hline & & & & Camphora 1M & & \\
\hline \multirow{5}{*}{ Cluster 2} & \multirow[t]{2}{*}{ Case 2} & \multirow[t]{2}{*}{50} & \multirow[t]{2}{*}{ Male } & Arsenic 30C & $\begin{array}{l}\text { Hydroxychloroquine } \\
400 \mathrm{mg}\end{array}$ & \multirow[t]{2}{*}{ RT-PCR } \\
\hline & & & & Camphora 200C & Azythromycin $500 \mathrm{mg}$ & \\
\hline & Case 3 & 45 & Female & Arsenic 30C & - & $\begin{array}{l}\text { Close contact } \\
\text { with case } 2\end{array}$ \\
\hline & Case 4 & 09 & Male & Arsenic 30C & - & $\begin{array}{l}\text { Close contact } \\
\text { with case } 2\end{array}$ \\
\hline & Case 5 & 07 & Male & Arsenic 30C & - & $\begin{array}{l}\text { Close contact } \\
\text { with case } 2\end{array}$ \\
\hline \multirow{6}{*}{ Cluster 3} & \multirow[t]{3}{*}{ Case 6} & \multirow[t]{3}{*}{62} & \multirow[t]{3}{*}{ Male } & Arsenic 30C & $\begin{array}{l}\text { Hydroxychloroquine } \\
400 \mathrm{mg}\end{array}$ & \multirow{3}{*}{$\begin{array}{l}\text { Confirmed } \\
\text { (method not } \\
\text { mentioned) }\end{array}$} \\
\hline & & & & Aconite 30C & \multirow[t]{2}{*}{ Azythromycin $500 \mathrm{mg}$} & \\
\hline & & & & Belladona 30C & & \\
\hline & \multirow[t]{3}{*}{ Case 7} & \multirow[t]{3}{*}{26} & \multirow[t]{3}{*}{ Female } & Arsenic 30C & $\begin{array}{l}\text { Hydroxychloroquine } \\
400 \mathrm{mg}\end{array}$ & \multirow{3}{*}{$\begin{array}{l}\text { Confirmed } \\
\text { (method } \\
\text { mentioned) }\end{array}$} \\
\hline & & & & Aconite 30C & \multirow[t]{2}{*}{ Azythromycin $500 \mathrm{mg}$} & \\
\hline & & & & Belladona 30C & & \\
\hline
\end{tabular}

Combined treatment using homeopathy and allopathy in Bhopal, Madhya Pradesh, India

A clinical trial data was available from Government Homeopathic Medical College, Bhopal, Madhya Pradesh, India. Total no of observed patient was 7 from 3 different clusters. 4 of them were treated collectively with homeopathy and allopathy but 3 of them were treated with homeopathy only.

\section{Conclusion}

As it is clear that allopathy is the mainstream treatment method throughout the world and WHO also does not recommend other treatment methods as the cure of COVID-19 except allopathy so it must be our main approach. But as we know that homeopathy has the advantage to use with allopathy as well as it is proved that it will not have any side effects to any age group of patients, starting from old to a baby. Furthermore, it is unclouded from the comparative statistical data of mortality rate under homeopathy and allopathy that homeopathy always served us in the previous pandemic. In addition to that, in Bhopal patients were treated successfully by the combined use of homeopathy and allopathy. So there is no reason for not attempting homeopathy alongside mainstream allopathy to treat the COVID-19 patient. Most of the elderly patients died because of poor immune system, so by combined homeopathy \& allopathy treatment we can significantly boost their immune system.

\section{References}

1. Singh R, Vijayan V. Chloroquine: A Potential Drug in the COVID-19 Scenario. Trans Indian Natl Acad Eng 2020;5(2):399-410

2. Harapan H, Itoh N, Yufika A, Winardi W, Keam S, Te H, et al. Coronavirus disease 2019 (COVID-19): A literature review. J Infect Public Health. 2020;13(5):667-73

3. Ali I, Alharbi OML. COVID-19: Disease, management, treatment, and social impact. Sci Total Environ 2020;728:138861.

4. Dozens of COVID-19 vaccines are in development. Here are the ones to follow. [Internet]. [cited 2020 Sep 7]. Available from: https://www.nationalgeographic.com/science/health-andhuman-body/human-diseases/coronavirus-vaccine-tracker-howthey-work-latest-developments-cvd/

5. Kaul D. An overview of coronaviruses including the SARS-2 coronavirus - Molecular biology, epidemiology and clinical implications. Curr Med Res Pract 2020;10(2):54-64

6. Funk CD, Laferrière C, Ardakani A. A Snapshot of the Global Race for Vaccines Targeting SARS-CoV-2 and the COVID-19 Pandemic. Front Pharmacol [Internet]. 2020 Jun 19 [cited 2020 Sep 7];11:1.

7. Lives saved by Homeopathy in Epidemics and Pandemics | Āgenskalna privātklīnika. [Accessed: 30-Aug-2020]. Available: http://www.similia.lv/interesanti/parhomeopatiju/lives-saved-by-homeopathy/.

8. Lombardi CM. Covid-19 Pandemic: The View From New York City. J Foot Ankle Surg. 2020;2019:1-4.

9. To KLA, Fok YYY. Homeopathic Clinical Features of 18 
Patients in COVID-19 Outbreaks in Hong Kong. Homeopathy. 2020;109(3):146-62.

10. (PDF) Symptomatic COVID-19 positive and likely patients treated by homeopathic physicians - an Italian descriptive study. [Accessed: 31-Aug-2020] Available: https://www.researchgate.net/publication/340631586_Sympto matic_COVID-

19_positive_and_likely_patients_treated_by_homeopathic_phy sicians_-_an_Italian_descriptive_study.

11. Nambison NK, Dhar Dwivedi A, Nambison SN. Pandemic COVID-19: Homeopathic prevention and treatment experiences. Int J Homoeopath Sci. 2020;4(2):265-70.

12. Coronavirus outbreak: Top coronavirus drugs and vaccines in development [Internet]. [cited 2020 Sep 7]. Available from: https://www.clinicaltrialsarena.com/analysis/coronavirus-merscov-drugs/

13. Coronavirus: Here are the top drugs and vaccines in development [Internet]. [cited 2020 Sep 7]. Available from: https://www.cnbc.com/2020/05/13/coronavirus-scientists-raceto-find-a-cure-or-vaccine-here-are-the-top-drugs-indevelopment.html

14. What is Oxford university's ChAdOx1 coronavirus (Covid-19) vaccine [Internet]. [cited 2020 Sep 8]. Available from: https://indianexpress.com/article/what-is/what-is-oxforduniversity-astrazeneca-chadox 1-coronavirus-covid-19-vaccine6515234/

15. INO-4800 DNA Coronavirus Vaccine - Precision Vaccinations [Internet]. [cited 2020 Sep 12]. Available from: https://www.precisionvaccinations.com/vaccines/ino-4800-dnacoronavirus-vaccine

16. Coronavirus Vaccine Inovio's COVID-19 vaccine shows encouraging early results, joins Trump's 'Warp Speed' | Health Tips and News [Internet]. [cited 2020 Sep 8]. Available from: https://www.timesnownews.com/health/article/inovios-covid19-vaccine-shows-encouraging-early-results-joins-trumpswarp-speed/614487

17. mRNA-1273 SARS-CoV-2 Vaccine - Precision Vaccinations [Internet]. [cited 2020 Sep 8]. Available from: https://www.precisionvaccinations.com/vaccines/mrna-1273sars-cov-2-vaccine

18. Jackson LA, Anderson EJ, Rouphael NG, Roberts PC, Makhene M, Coler RN, et al. An mRNA Vaccine against SARS-CoV-2 - Preliminary Report. N Engl J Med. 2020;
19. What Is Remdesivir, the First Drug That Treats Coronavirus? | Discover Magazine [Internet]. [cited 2020 Sep 8]. Available from: https://www.discovermagazine.com/health/what-is-remdesivirthe-first-drug-that-treats-coronavirus

20. Grein J, Ohmagari N, Shin D, Diaz G, Asperges E, Castagna A, et al. Compassionate use of remdesivir for patients with severe Covid-19. N Engl J Med. 2020;382(24):2327-36. 21. Vincent MJ, Bergeron E, Benjannet S, Erickson BR, Rollin PE, Ksiazek TG, et al. Chloroquine is a potent inhibitor of SARS coronavirus infection and spread. Virol J. 2005 Aug $22 ; 2$.

22. Mahmud, Shamim Hasan M, Sardar RI, Miah B. Use of different Drugs and Plasma Therapy against Treatment of COVID-19: South Korea- based Overall Perspective. Bauet J. 2020;2(August):97-103.

23. Oxford Coronavirus Vaccine | Oxford-AstraZeneca COVID-19 vaccine phase 1 trial data to be released on July 20 | Health Tips and News [Internet]. [cited 2020 Sep 8]. Available from: https://www.timesnownews.com/health/article/oxfordastrazeneca-covid-19-vaccine-phase-1-trial-data-to-be-releasedon-july/622199

24. Folegatti PM, Ewer KJ, Aley PK, Angus B, Becker S, Belij-Rammerstorfer S, et al. Safety and immunogenicity of the ChAdOx1 nCoV-19 vaccine against SARS-CoV-2: a preliminary report of a phase $1 / 2$, single-blind, randomised controlled trial. Lancet 2020;396(10249):467-78.

25. Coronavirus Vaccine Tracker - The New York Times [Internet]. [cited 2020 Sep 7]. Available from: https://www.nytimes.com/interactive/2020/science/coronavirus -vaccine-tracker.html

26. INOVIO's COVID-19 DNA Vaccine INO-4800 Provides Protection with Memory Immune Responses In Non-Human Primates Challenged with SARS-CoV-2 Virus [Internet]. [cited 2020 Sep 8]. Available from: https://www.prnewswire.com/news-releases/inovios-covid-19dna-vaccine-ino-4800-provides-protection-with-memoryimmune-responses-in-non-human-primates-challenged-withsars-cov-2-virus-301103039.html

27. INO-4800 DNA Coronavirus Vaccine - Precision Vaccinations [Internet]. [cited 2020 Sep 8]. Available from: https://www.precisionvaccinations.com/vaccines/ino-4800-dnacoronavirus-vaccine 